Van Dyk, “"Responsible Stewardship,”” OTE 24/2 (2011): 523-535

\title{
"Responsible Stewardship" - The Root of All Evil in Eco-Theology?*
}

\author{
Peet J. VAn Dyk (Unisa)
}

\begin{abstract}
Responsible stewardship of the earth has often been hailed by ecotheologians as an important corrective to an exploitative dominionorientated attitude towards the earth. The idea of "responsible stewardship" is then introduced as a possible way to soften this harsh view of dominion over nature. The Garden in Eden and especially the command in Gen 2:15 to "till" and "guard" it is often quoted in eco-theology as an argument why humans should take on this responsibility towards nature conservation. This view can either be supported by a historical or a metaphorical argument. It is however argued that Eden should not be used in either way: Eden was not located within historical times or within a historical setting and the Garden of Eden is described in terms exactly opposite to those used to describe nature or wilderness: that is, as a well-farmed garden or agricultural field. It is further argued that the term "responsible stewardship" may be problematic from an ecological perspective. Contemporary ecology has demonstrated that nature does not need constant interference and is naturally selfsustaining. The term "responsible stewardship" may therefore merely be a hidden new way to affirm human dominion, human arrogance and anthropocentrism. It is therefore suggested that the terms "reluctant interference" or "careful interference" should rather be used than the concept of "responsible stewardship."
\end{abstract}

Keywords: Eco-theology, responsible stewardship, Garden of Eden, careful interference, reluctant interference.

\section{A COMING TO THE RESCUE}

Theologians tend to belong to a species that is very quick to come to the rescue of whoever needs it. It is therefore not surprising that now that it is wellacknowledged that our earth is in a terrible mess, theologians would come running to try and rescue it. This has led to a new breed of activist theologians who call themselves eco-theologians, green theologians or by various other names. ${ }^{1}$

* To cite: Peet J. van Dyk, “'Responsible Stewardship' - The Root of All Evil in Eco-Theology?" OTE 28, no. 2 (2015): 523-535. DOI: http://

dx.doi.org/10.17159/2312-3621/2015/v28n2a16 
In almost all cases this rescue operation has been done under the banner of "responsible stewardship," based primarily on the text in Gen 2:15 where humans are given the task by Yahweh to act as gardeners in the mythical Garden of Eden, that is, to "work/till" (עבד) and "to guard" (שמר) it. Taken out of context, these words can easily be linked to our modern concept of conservation and be interpreted as "responsible stewardship" over the earth. ${ }^{2}$ Such an interpretation would then give theologians permission to tackle a new worthwhile cause (i.e. the ecological crisis), something they can pursue with diligence and righteous enthusiasm.

An added bonus to this emphasis on human responsibility to till and guard the Garden is that it could potentially "soften" the impact of the embarrassing text in Gen 1:28 $8^{3}$ where humans were commanded to trample (כבש) and to have dominion (רדה) over the earth. ${ }^{4}$

But unfortunately this popular view about responsible stewardship over the earth has a number of serious problems that could be challenged on three basic grounds. The first two are based on exegetical grounds and the third one is built on broader biological/ecological principles. These problems can be listed as follows:

(i) Where exactly were the first humans placed?

(ii) Exactly what were the first humans supposed to do in the Garden in Eden?

(iii) Is a high-handed management of the ecosystem desirable?

1 Cf. Steve Bishop, "Green Theology and Deep Ecology: New Age or New Creation?" Themelios 16/3 (1991): 8-14; Valerie Brown, "The Rise of Ecotheology," n.p. [cited 11 December 2014]. Online: http://www.columbia.edu/cu/21stC/issue3.4/brown.html.

2 See Jürgen Moltmann, God in Creation: An Ecological Doctrine of Creation (London: SCM, 1985); Jimmie A. Loader, "Image an Order: Old Testament Perspectives on the Ecological Crisis," in Are We Killing God's Earth? (ed. Willem Vorster; Pretoria: University of South Africa, 1987), 6-28; Gene M. Tucker, "Rain on a Land where No One Lives: The Hebrew Bible on the Environment," JBL 116/1 (1997): 4; and Nicola H. Creegan, "Theological Foundations of the Ecological Crisis," Stimulus 12/4 (2004): 32.

3 Cf. Lynn White, "The Historical Roots of Our Ecological Crisis," Science 155 (1967): 1203-1207.

4 Gene M. Tucker, "Creation and the Limits of the World: Nature and History in the Old Testament," HBT 15 (1993): 107. Even though Gen 1:28 can be interpreted as ruling over the earth in responsibility towards God (like vassal kings), this does not necessarily imply ruling in an eco-sensitive way. 
The dual purpose of this article is: 1) to explore the assumptions being made when using Eden as a metaphor for nature and when applying God's command to "work" and "protect" the garden in such a way that it would include nature conservation and environmental protection; and 2) to question the underlying assumptions when viewing nature as somehow insufficient and thus in need of human management.

Before exploring these two questions it is necessary to first investigate the two possible ways in which Eden can be used as part of an argument for human responsibility towards nature.

\section{B TWO POSSIBLE WAYS EDEN COULD BE USED}

Genesis 2:15 can be interpreted in two possible ways to argue in favour of our responsibility towards nature: 1) as part of a historical argument; or 2) as part of a metaphorical argument.

The historical argument could be phrased as follows: "When God created the Garden in Eden, he appointed humans as its guardian. Humans therefore have the historical duty or right to look after Eden, that is, the earth." This historical argument assumes (although it is not always explicitly argued) that Gen 2:15 should be interpreted in a literal sense as referring to a historical place and time within our cosmic reality. Logically the historical argument could only work (or be convincing) if this so-called historical right or duty is based on an actual historical event and place. ${ }^{5}$ It would for example be absurd to argue that humans have a "historical duty" to investigate all strange phenomena, based on the fact that Alice followed a strange looking rabbit, with a waistcoat and a pocket watch, down a rabbit hole. ${ }^{6}$

Contrary to the historical argument, the metaphorical argument does not depend on the historicity of the metaphor. As part of a metaphorical argument Eden can therefore be interpreted as a symbol for nature or the wilderness, ${ }^{7}$ even if Eden was not a historical place. The metaphorical argument therefore has a different prerequisite than the historical argument: for it to work (or to be convincing) the relationship between the metaphor (e.g. the Garden in Eden),

5 Many OT exegetes/readers are logically inconsistent: on the one hand they strongly maintain that the bible is NOT a handbook of science and that the creation narratives do not reflect actual history, whilst on the other hand they argue that humanity's stewardship over nature is a "historical responsibility" due to the fact that Yahweh instructed the first humans to "till and guard" the garden.

6 Cf. Lewis Carroll, Alice's Adventures in wonderland (Millennium ed. 3.0), n.p. [cited 13 May 2015]. Online: http://www.gutenberg.org/files/11/11-h/11-h.htm.

${ }^{7}$ The term "wilderness" will be used in the ordinary dictionary sense as "a tract or region uncultivated and uninhabited by human beings." See "Wilderness," MerriamWebster Dictionary, 2011, n.p. [cited 13 May 2015]. Online: http://www.merriamwebster.com/dictionary/wilderness. 
and that which is symbolised (i.e. nature or wilderness) should be self-evident. If this is not the case the metaphor will be experienced as forced or contrived and will therefore not be convincing. Arbitrarily chosen metaphors cannot symbolise just any given concept. For example, to use the lion as a metaphor for peace and non-violence would not work, because lions are vicious carnivores that kill for a living. For this reason lions are more appropriately used as metaphors for bravery in warfare, as is evident from its abundant usage in coats of arms throughout the ages. ${ }^{8}$

If the above reasoning, that metaphors should be appropriate, is accepted then it implies that Eden could only be used by eco-theologians as a metaphor for nature if: 1) the picture painted of Eden in Gen 2-3 is congruent with nature or wilderness; and 2) if the task of the first humans in the Garden was indeed to protect this wilderness by not allowing, for example, agricultural activities which would change its wilderness character.

First we will consider the possible historical duty of humans to preserve nature and secondly how appropriate it is to use Eden as a metaphor for nature or wilderness, irrespective of its historical existence.

\section{A HISTORICAL DUTY?}

The transference of the Garden of Eden to symbolise nature or wilderness has become popular both amongst lay persons and within theological circles. ${ }^{9}$ This view uncritically assumes that Eden referred to a real earthly setting within historical time. It is therefore necessary to explore this assumption by tracing the reception history of Gen 2-3 and while doing it critically investigate the assumed historicity of mythological literature, including the biblical creation narratives.

Contemporary scholars have convincingly argued that religious myths were NOT regarded as fiction by its first audience, but as literal truth. ${ }^{10}$ As such these myths fulfilled the function of explaining and legitimising the status quo (or cosmology) of its time, by using a "historical argument.",

8 Cf. Osten Hallberg, "Lion symbol," n.p. [cited 11 December 2014]. Online: http://www.animal-symbols.com/lion-symbol.html.

9 Cf. for example James Stevenson-Hamilton, South African Eden (Andover: The Chapel River Press, 1937) who described the Kruger National Park in South Africa as Eden.

10 Cf. Hubert Cancik, Mythische und historische Wahrheit: Interpretationen zu Texten der hethitischen, biblischen und griechischen Historiographie (Stuttgart: Verlag Katholisches Bibelwerk, 1970).

11 For example, the purpose of the Babylonian Enuma Elish creation myth was to legitimise and explain how Marduk gained the "historical right" to become the king of the gods and by doing this displacing the older Babylonian gods in the process. As 
However, the supposed historicity of ancient myths already became suspect in Ancient Greece when philosophers started to challenge the magicomythical cosmology of the ancient world. ${ }^{12}$ An increasing emphasis on immediate natural causes rather than ultimate supernatural causes was typical of especially Aristotle and his school of thought. In line with this, the Greek philosopher Chrysippus (3rd century B.C.E.) started interpreting the Homeric poems in an allegoric or symbolic way "to eliminate offensive material from a religious text." ${ }^{2}$ This allegorical interpretation of Homer implied that his works were no longer interpreted as literally true. For example, when it is narrated in the Iliad that the gods Deimos and Phobos created panic and rout amongst the Greek and Trojan soldiers, the literal interpretation of this statement (within its magico-mythical cosmology) would entail that the two gods literally came down to earth, walked amongst the soldiers and created panic and rout on the battlefield by their mere presence. An allegorical or symbolic interpretation of this incident would interpret Deimos merely as the symbol for panic and Phobos as the symbol for rout. It is interesting to note that many English translations of the Iliad consciously or unconsciously followed this allegorical interpretation by merely translating the Greek word Deimos with Panic and the word Phobos with Rout, without any explicit reference to the gods, except for the capitalisation. ${ }^{14}$

This symbolic or allegorical interpretation of religious myths was also transferred to the Hebrew/Christian Bible when the church father Origin introduced the allegorical or symbolic interpretation of the Bible into biblical

argued earlier, this "historical argument" could only be convincing if the first audience believed in the literal truth of their myths.

12 This ancient challenge to the magico-mythical cosmology was brought to its logical conclusion during the Enlightenment. Cf. Peter Gay, The Enlightenment: An Interpretation: The Rise of Modern Paganism (London: Weidenfeld \& Nicholson, 1966), 34: "The Enlightenment's conception of history as a continuing struggle between two types of mentalities implies a general scheme of periodization. The philosophes divided the past roughly into four great epochs: the great river civilizations of the Near East; ancient Greece and Rome; the Christian millennium; and modern times .... . These four epochs were rhythmically related to each other: the first and third were paired off as ages of myth, belief, and superstition, while the second and fourth were ages of rationality, science, and enlightenment."

13 Cf. Hans-Georg Gadamer, Truth and Method (2nd ed.; trans. J. Weinsheimer and D. G. Marshall; London: Sheed \& Ward, 1989), 73.

14 E.g. the translation by Samuel Butler of Homer, The Iliad: Book 4 (trans. Samuel Butler), n.p. [cited 12 May 2015]. Online: http://classics.mit.edu/Homer/iliad.4.iv .html. 
hermeneutics - a view that would dominate biblical hermeneutics during most of the Middle Ages. ${ }^{15}$

With the arrival of the Renaissance and its Christian companion - the Reformation - came a return to the assertion that the biblical creation narratives should be interpreted as literal truth. In a sense this is ironic since the Renaissance largely depended on the insights of the classical Greek philosophers, who did exactly the opposite by starting to interpret their religious myths allegorically.

However, this literal interpretation of the biblical creation narratives was soon challenged when critical OT scholars (within the historical-critical school of thought) started in the 1700's to question the historicity of certain biblical texts (especially the creation narratives). The mythical school of Eichhorn and Gabler labelled the creation narratives as myths and by this they implied (as Chrysippus did with Homer) that Gen 1-3 should not be interpreted in a literal way. For example, Gabler criticised any attempt to interpret Gen 1-3 as a historical account by saying the following:

Teilweise hat man gar die Mythen als wahre Geschichten hingenommen und "dadurch die ganze Bibel dem Spotte ihrer Feinde preisgegeben." 16

Most critical scholars nowadays similarly accept that the biblical creation narratives should not be interpreted as literal history and that they are not compatible with our contemporary scientific cosmology. ${ }^{17}$ This unhistorical and unscientific nature of the biblical creation narratives becomes especially clear when the biblical text is read against the magico-mythical cosmology of its time and the reader is thus confronted with its dated view suggesting a flat earth disc, resting on pillars in the primeval flood. Within this magico-mythical cosmology Eden was most probably imagined to be located on the edge of the world, that is, on the eastern horizon (where heaven, earth and underworld were supposed to have met). The setting of the Garden was therefore not to be

15 Cf. Peter Harrison, "Subduing the Earth: Genesis 1, Early Modern Science, and the Exploitation of Nature," JR 79/1 (1999): 90. This does not imply that Origin's allegorical interpretation was exactly the same as later symbolic interpretations of the biblical text, but merely wishes to state that it was another possible kind of symbolic interpretation.

16 Cf. Hans-Joachim Kraus, Geschichte der historisch-kritischen Erforschung des Alten Testaments (3rd ed.; Neukirchen-Vluyn: Neukirchener Verlag, 1982), 150.

17 However, a large number of conservative scholars tenaciously wish to maintain some kind of historicity for the biblical creation narratives, although they may superficially agree that the Bible is not a handbook of science. See Peet J. van Dyk "The Bible and Evolution: Opinions amongst Southern African Clergy and Theologians from the Reformed Church Tradition," VEccl 34/1 (2013), Art. \#776, 9 pages; DOI : 10.4102/ ve.v34i1.776. 
Van Dyk, “"Responsible Stewardship,” OTE 24/2 (2011): 523-535

located within the ordinary living space of humans, but rather within mythical space. ${ }^{18}$

Therefore if the Garden in Eden was imagined to be located in mythical space it would be a logical fallacy to use a historical argument when arguing for human responsibility towards nature. In short, it cannot be argued that humans have a historical duty to look after nature (Gen 2:15), based on the supposedly "historical role" assigned to the first humans in the Garden in Eden, if no such garden ever existed in historical space or time.

If the historical-duty-argument does not hold water then it leaves us only with the second possibility, that is, to interpret Eden as a metaphor for nature or wilderness.

\section{CAN EDEN BE USED AS A METAPHOR FOR NATURE?}

As argued earlier, Eden can only be used as a successful or legitimate metaphor for nature if Eden was indeed described as a natural wilderness and if the task of the first humans was to protect this wilderness character. If these two provisions are not met, the metaphor would be based on a "corrupted" popular view of the meaning of the biblical text, contrary to its original intention.

There is little doubt that the picture painted of the Garden in Eden in Gen 2-3 came from the agricultural milieu: God "planted" (נטע) the Garden (Gen 2:8) like a Palestinian farmer would lay out a grove of olive trees. The trees were "pleasant to look at" (נחמד למראה) and "good to eat from" (טובה למאכל ), suggesting that it is not nature or the wilderness that is described here, but rather a park-like plantation of fruit and decorative trees. Eden is further irrigated by four irrigation canals or cosmic rivers, similar to the way farm plots were irrigated along the major rivers of Mesopotamia and Egypt.

Similarly to Eden, the garden of the gods on the eastern horizon was described in ANE myths as a place of opulence, where the grain grows a few meters high, where the Bull of heavens graze and as a place which provided food for the gods. ${ }^{19}$

18 Cf. Terje Stordalen, Echoes of Eden: Genesis 2-3 and Symbolism of the Eden Garden in Biblical Hebrew Literature (Leuven: Peeters, 2000), 285; and Peet J. van Dyk, "In Search of Eden: A Cosmological Interpretation of Genesis 2-3," OTE 27/1 (2014): 651-665.

19 In Egyptian mythology the garden of the gods is described as follows: "I know that Field of Reeds of Re. The wall which is around it is of metal. The height of its barley is four cubits . . . Its emmer is seven cubits . . . It is the horizon-dwellers, nine cubits in height, who reap it, by the side of the Eastern Souls." Cf. ANET, 33; and Christopher Woods, "At the Edge of the World: Cosmological Conceptions of the Eastern Horizon in Mesopotamia,” JANER 9/2 (2009): 203-204. 
The Garden of Eden is therefore not described as a wild stretch of nature, but rather as a garden or park laid out by a farmer (in this case God) and as a place which was probably enclosed by a wall - as is suggested by the Hebrew word $\{$ and by the fact that the first humans could be chased from it and that Cherubs could guard its entrance (Gen 3:24).

The agricultural image of a garden or plantation is further strengthened by the task given to the first humans. Yahweh commanded humans "to work/till" (עבד) and "to guard" (שמר) the Garden. Most exegetes agree that these words should be understood in the context of Palestinian agriculture. ${ }^{20}$ The necessity of working and guarding one's garden is graphically described in the song of the vineyard in Isa 5, where the gardener tilled the ground, removed stones and planted it with vines. He further built a guarding tower to protect his vineyard against animals and marauders. Tilling and guarding a garden or field were therefore common descriptions for the task of a Palestinian farmer.

If this agricultural context is taken seriously it means that God instructed the first humans (in our modern idiom) "to plough the fields, maintain the irrigation canals and tame the wilderness by diligently pruning and keeping everything intact and thus keep the wilderness at bay." The purpose of this command was clearly to ensure that Eden would look something like our welltended parks and would not become a chaotic wilderness.

Eden is therefore also NOT an appropriate metaphor for nature conservation, because Eden is neither described as natural wilderness, but as a cultivated park, nor was the task of the first humans to preserve its wilderness character, but rather to farm and cultivate it by "taming the wilderness."21

\section{E SHOULD NATURE BE MANAGED?}

Independent of the question if Eden could be used either as a historical or as a metaphorical argument to support the idea of human responsibility towards nature, is the question why humans think that nature needs constant

20 Cf. Claus Westermann, Genesis 1-11 (2nd ed.; Neukirchen-Vluyn: Neukirchener Verlag, 1976), 301: "Es ist wohl richtig, daß dem Erzähler zunächst die Arbeit des palästinischen Bauern vor Augen steht bei diesen beiden Verben 'bebauen und bewahren"; and Arie van der Kooij, "The Story of Paradise in the Light of Mesopotamian Culture and Literature," in Genesis, Isaiah, and Psalms: A Festschrift to Honour Professor John Emerton for his Eightieth Birthday (ed. Katherine J. Dell, Graham I. Davies and Yee Von Koh; Leiden: Brill, 2010), 15-16, puts more emphasis on the word "guard" and therefore sees the task more as guardian of a royal garden.

21 Even though the "wild animals of the veld" and birds are mentioned in Gen 2:1920 it is not explicitly said that these wild animals inhabited the garden, but merely that God brought them to the first humans to name. In the ancient context of the perceived hostility between wilderness and agricultural land it is unlikely that wild animals were supposed to inhabit the park in Eden in any great numbers. 
management. Can we be so arrogant to think that we know it all and that our "interference" in nature, even if well-intended, will necessarily have a positive effect on ecosystems?

In our day and age the idea of management has become a popular concept, often implying that everything needs to be managed, including nature. If this view is accepted, it implies that a detailed management plan needs to be drawn up for nature, which would comprise an active micro-management of earthly ecosystems. Such an envisioned management programme of nature is often justified theologically by arguing that nature was corrupted during the fall and that the earth was cursed by God (Gen 3:17). Such a view can then be used to argue why the earth needs restoration and why it may be expected from humans to achieve this through responsible stewardship and by active human intervention. $^{22}$

This theological legitimisation of the high-handed management of nature was congruent with the widespread perception (until the middle 1800's) that the wilderness (i.e. nature) was something bad and hostile. ${ }^{23}$ The wilderness therefore needed to be tamed by converting it either into a well-kept park/garden or into an agricultural field (similar to Eden). Such a "tamed" wilderness would need constant human interference or intervention to maintain it in its so-called "prime condition" [sic!].

The above out-dated view, that constant human interference into nature is imperative, is diametrically opposed to the more laissez faire approach advocated by contemporary ecology. Contemporary ecology has convincingly demonstrated that nature is best left alone, because ecosystems function optimally when natural processes are allowed to function undisturbed by human action. ${ }^{24}$ Perrow and Davy argued that even in the case of previously disturbed ecosystems the ideal of habitat restoration should be to reestablish a self-maintaining ecosystem, rather than a system that would need continual human management. They formulated their view as follows: "Habitat

22 Cf. Harrison, "Subduing," 105-106.

23 Cf. George H. Stankey, "Beyond the Campfire's Light: Historical Roots of the Wilderness Concept," NRJ 29 (1989): 20. This hostility towards the wilderness is also evident in the Bible: Cf. Robert B. Leal, Wilderness in the Bible: Toward a Theology of Wilderness (New York: Peter Lang, 2004).

${ }^{24}$ Paul W. Taylor, Respect for Nature: A Theory of Environmental Ethics (25th anniversary ed.; Princeton, N.J.: Princeton University Press, 2011), 196, argues that even in case where nature was damaged it is sometimes possible to make restitution without again interfering. 
restoration aims to achieve complete structural and functional, self-maintaining biological integrity following disturbance." 25

From an ecological point of view the concept of human stewardship is therefore problematic if it implies that nature is somehow deficient in maintaining itself and that a healthy ecosystem could only be maintained through constant human interference. One can rightly ask if such a view is not just another example of human arrogance and anthropocentrism, especially when we present ourselves as God-appointed stewards of the earth. By assuming that we always know what is best for nature we often ignore the many unanticipated negative results of human interference into nature, even when such interference was done with the best intentions and under the banner of "responsible stewardship."

An example of such human interference, in a mostly natural ecosystem, was the establishment of a large number of artificial water holes in the Kruger National Park (South Africa) during the second half of the 1900's. The wellintended purpose of these water holes was to provide life-giving water to animals, especially during the dry winter months. The unanticipated negative results of these water holes were excessive soil erosion and the negative impact it had on scares antelope species like Roan Antelope, which could not successfully compete with other species in the newly created water-rich habitat. ${ }^{26}$ High-handed management of nature can therefore sometimes do more damage than good.

However, a complicating factor for ecologists is the fact that large parts of nature have already been damaged by human actions. ${ }^{27}$ This raises the ethical problem which Taylor calls the conflict between the "duties of noninterference and restitutive justice." Non-interference is not always an ethically sound option when we are dealing with an already damaged ecosystem. In such a case some kind of restitution may be imperative to try and restore damage, previously caused by human action. For example, it would be acceptable to put up barriers to prevent animals from entering a place where radioactive waste has been leaking into the ground. ${ }^{28}$

It should therefore be concluded that human interference and management of nature should be done with far more care and humbleness than previously done. As humans we should not (again) fall into the arrogance trap

25 Martin R. Perrow and Anthony J. Davy, Handbook of Ecological Restoration: Restoration in Practice (vol. 2, Cambridge: Cambridge University Press, 2002), i.

26 Sanparks, "Media Release: KNP to Close More Artificial Water Holes," n.p. [cited 9 June 2015]. Online: www.sanparks.org/parks/kruger/news.php.

27 Cf. Taylor, Respect, 4: "Doubts might be raised as to whether any genuinely natural ecosystems now exist on our planet."

28 Taylor, Respect, 196. 
Van Dyk, “'Responsible Stewardship,” OTE 24/2 (2011): 523-535

by thinking that we know exactly what is required to put the earth back on its tracks. Declaring ourselves as "responsible stewards" over the earth may therefore merely be a hidden new way to affirm human dominion, human arrogance and anthropocentrism. ${ }^{29}$

\section{E CONCLUSIONS}

Notwithstanding the popular idea that the Garden in Eden could be equated with nature, Eden could and should not be used either as part of a historical nor as part of a metaphorical argument to claim human responsibility towards nature conservation. The Garden in Eden was not located within historical time or a historical setting and thus could not be used to argue that humans have a "historical duty" to protect nature. Eden should also not be used as a metaphor for nature conservation (irrespective of its historicity), because the Garden in Eden was described in Gen 2-3 as exactly the opposite of what we would today call nature or wilderness. The picture of the Garden in Eden is one of a wellfarmed agricultural plantation or park, consisting mainly of fruit trees, which were actively "farmed" by the first humans and probably walled to protect it from the wilderness.

It is further concluded that, independent from the fact if Eden is used to argue the case of supposed human stewardship over the earth, the term "responsible stewardship" may be problematic from an ecological perspective. Contemporary ecology has demonstrated that nature do not need constant interference and is naturally self-sustaining. As stated above, the term "responsible stewardship" may therefore merely be a hidden new way to affirm human dominion, human arrogance and anthropocentrism.

I would therefore like to suggest that in those cases where human interference into nature is necessitated by the fact that previous human damage to ecosystems needs to be corrected (e.g. in the case of restoration ecology) the terms "reluctant interference" or "careful interference" should be used to acknowledge the inherent dangers in such corrective measures.

\section{BIBLIOGRAPHY}

Bishop, Steve. "Green Theology and Deep Ecology: New Age or New Creation?" Themelios 16/3 (1991): 8-14.

Brown, Valerie. "The Rise of Ecotheology." No Pages. Cited 11 December 2014. Online: http://www.columbia.edu/cu/21stC/issue-3.4/brown.html.

Cancik, Hubert. Mythische und historische Wahrheit: Interpretationen zu Texten der hethitischen, biblischen und griechischen Historiographie. Stuttgart: Verlag Katholisches Bibelwerk, 1970.

29 Harrison, "Subduing," 89. 
Carroll, Lewis. Alice's Adventures in Wonderland. Millennium ed. 3.0. Project Gutenberg. No Pages. Cited 13 May 2015. Online:

http://www.gutenberg.org /files /11/11-h/11-h.htm.

Creegan, Nicola H. "Theological Foundations of the Ecological Crisis." Stimulus 12/4 (2004): 30-34.

Gadamer, Hans-Georg. Truth and Method. 2nd ed. Translated by J.

Weinsheimer and D. G. Marshall. London: Sheed \& Ward, 1989.

Gay, Peter. The Enlightenment: An Interpretation: The Rise of Modern

Paganism. London: Weidenfeld \& Nicholson, 1966.

Hallberg, Osten. “Lion Symbol.” No Pages. Cited 11 December 2014. Online: http://www.animal-symbols.com/lion-symbol.html.

Homer. The Iliad: Book 4. Translated by Samuel Butler. No Pages. Cited 12 May 2015. Online: http://classics.mit.edu/Homer/iliad.4.iv.html.

Harrison, Peter. "Subduing the Earth: Genesis 1, Early Modern Science, and the Exploitation of Nature." The Journal of Religion 79/1 (1999): 86-109.

Kraus, Hans-Joachim. Geschichte der historisch-kritischen Erforschung des Alten Testaments. 3rd ed. Neukirchen-Vluyn: Neukirchener Verlag, 1982.

Leal, Robert B. Wilderness in the Bible: Toward a Theology of Wilderness. New York: Peter Lang, 2004.

Loader, Jimmie A. "Image an Order: Old Testament Perspectives on the Ecological Crisis." Pages 6-28 in Are We Killing God's Earth? Edited by Willem Vorster. Pretoria: University of South Africa, 1987.

Merriam-Webster Dictionary. 2011. No Pages. Cited 13 May 2015. Online: http://www.merriam-webster.com.

Moltmann, Jürgen. God in Creation: An Ecological Doctrine of Creation. London: SCM, 1985.

Perrow, Martin R. and Anthony J. Davy. Handbook of Ecological Restoration: Restoration in Practice. Volume 2. Cambridge: Cambridge University Press, 2002.

Pritchard, James B. Ancient Near Eastern Texts Relating to the Old Testament. 2nd ed. Princeton, N.J.: Princeton University Press, 1955.

Sanparks, "Media Release: KNP to Close More Artificial Water Holes." No Pages. Cited 9 June 2015. Online: www.sanparks.org/parks/kruger/news.php.

Stankey, George H. "Beyond the Campfire's Light: Historical Roots of the Wilderness Concept." Natural Resources Journal 29 (1989): 9-24.

Stevenson-Hamilton, James. South African Eden. Andover: The Chapel River Press, 1937.

Stordalen, Terje. Echoes of Eden: Genesis 2-3 and Symbolism of the Eden Garden in Biblical Hebrew Literature. Leuven: Peeters, 2000.

Taylor, Paul W. Respect for Nature: A Theory of Environmental Ethics. 25th anniversary edition. Princeton, N.J.: Princeton University Press, 2011.

Tucker, Gene M. "Creation and the Limits of the World: Nature and History in the Old Testament." Horizons in Biblical Theology 15 (1993): 105-118. 
Van Dyk, ““Responsible Stewardship,” OTE 24/2 (2011): 523-535

"Rain on a Land where No One Lives: The Hebrew Bible on the Environment." Journal of Biblical Literature 116/1 (1997): 3-17.

Van der Kooij, Arie. "The Story of Paradise in the Light of Mesopotamian Culture and Literature." Pages 1-22 in Genesis, Isaiah, and Psalms: A Festschrift to Honour Professor John Emerton for his Eightieth Birthday. Edited by Katherine J. Dell, Graham I. Davies and Yee Von Koh. Leiden: Brill, 2010.

Van Dyk, Peet J. “The Bible and Evolution: Opinions Amongst Southern African Clergy and Theologians from the Reformed Church Tradition." Verbum et Ecclesia 34/1 (2013). Art. \#776. 9 pages. DOI : 10.4102/ ve.v34i1.776.

. "In Search of Eden: A Cosmological Interpretation of Genesis 2-3." Old Testament Essays 27/2 (2014): 651-665.

Westermann, Claus. Genesis 1-11. 2nd ed. Neukirchen-Vluyn: Neukirchener Verlag, 1976.

White, Lynn. "The Historical Roots of Our Ecological Crisis.” Science 155 (1967): 1203-1207.

Woods, Christopher. "At the Edge of the World: Cosmological Conceptions of the Eastern Horizon in Mesopotamia." Journal of Ancient Near Eastern Religions 9/2 (2009): 183-239.

Prof Peet J. van Dyk, Department of Biblical and Ancient Studies, University of South Africa. Email: vdykpj1@unisa.ac.za 